OPEN ACCESS

Edited by:

Simone Libralato,

National Institute of Oceanography and Experimental Geophysics, Italy

Reviewed by:

Michele Gristina,

Consiglio Nazionale Delle Ricerche

(CNR), Italy

Marta Coll,

Institut de Ciència de Materials de

Barcelona (CSIC), Spain

*Correspondence:

Angel Pérez-Ruzafa ange/pr@um.es

Specialty section: This article was submitted to Marine Affairs and Policy, a section of the journal Frontiers in Marine Science

Received: 17 March 2017

Accepted: 19 July 2017

Published: 03 August 2017

Citation

Pérez-Ruzafa A, García-Charton JA and Marcos C (2017) North East Atlantic vs. Mediterranean Marine Protected Areas as Fisheries Management Tool.

Front. Mar. Sci. 4:245 doi: 10.3389/fmars.2017.00245

\section{North East Atlantic vs. Mediterranean Marine Protected Areas as Fisheries Management Tool}

\author{
Angel Pérez-Ruzafa *, José A. García-Charton and Concepción Marcos \\ Departamento de Ecología e Hidrología, Facultad de Biología, Campus Mare Nostrum - Universidad de Murcia, Murcia, Spain
}

The effectiveness of management initiatives implemented in the context of the European Common Fisheries Policy has been questioned, especially with regard to the Mediterranean. Some of the analyses made to compare the fishing activity and management measures carried out in the North East Atlantic and in the Mediterranean do not take into account some of the differentiating peculiarities of each of these regions. At the same time, they resort to traditional fisheries management measures and do not discuss the role of marine protected areas as a complementary management tool. In this respect, the apparent failure of marine protected areas in the North-East Atlantic compared with the same in the Mediterranean is challenging European fishery scientists. Application of the classical holistic view of ecological succession to the functioning of fishery closures and no-use areas highlights the importance of combining both management regimes to fully satisfy both fishery- and biodiversity-oriented goals. We advocate that an optimal management strategy for designing an MPA to protect biodiversity and sustain fishing yields consists of combining a network of no-use areas (close to their mature state) with fish boxes (buffer zones maintained by fishing disturbance in a relatively early successional stage, where productivity is higher), under a multi-zoning scheme. In this framework, the importance of no-use areas for fisheries is based on several observations: (1) They preserve biological diversity at regional scale, at all levels-specific, habitat/seascape, and also genetic diversity and the structure of populations, allowing natural selection to operate. (2) They permit the natural variability of the system to be differentiated from the effects of regulation and to be integrated in appropriate sampling schemes as controls. (3) They maintain the natural size and age structure of the populations, hence maximizing potential fecundity, allowing biomass export to occur from core to regulated areas, dampening the fluctuations derived from deviations from the theoretical optimal effort in the fishing zone.

Keywords: North East Atlantic, Mediterranean, Marine Protected Areas, fisheries, management

\section{INTRODUCTION}

The effectiveness of management initiatives implemented in the context of the European Common Fisheries Policy (CFP), operative since 1984, has been put into doubt and the fisheries management system in Europe has been strongly criticized (Froese, 2011a,b). Immediately, providing data on the evolution of some traditional fisheries, Cardinale (2011) countered those claims. Since 
then, attention has focused particularly on the situation in the Mediterranean Sea, where the alarming decline of its fish stocks is a matter of increasing concern (Vasilakopoulos et al., 2014; Cardinale and Scarcella, 2017). This is especially evident when comparing the effectiveness of fisheries management in the North East Atlantic and the Mediterranean. According to these reviews, NE Atlantic fish stocks have been gradually recovering as a result of the decrease in fishing pressure following implementation of the EU's CFP during the past decade (Cardinale, 2011), while European Mediterranean fish stocks seem to be out of control, and regulations are often poorly enforced (Vasilakopoulos et al., 2014; Cardinale and Scarcella, 2017).

Most of the above mentioned analyses focus on stocks caught by trawlers and purse seines, both characteristic of open waters and relatively deep bottoms, and propose management actions based on traditional fisheries management tools consisting of limiting juvenile exploitation, harvesting species a few years after maturation, and changes in selectivity and exploitation rates (Selig et al., 2017). It is expected that these measures should maximize long-term yields and halt stock depletion (Hilborn and Ovando, 2014), and are in accordance with the EU's CFP, which requires that fish stocks should be exploited at a level that generates the maximum sustainable yield (MSY; European Commission, 2006; Vasilakopoulos et al., 2014).

However, Mediterranean and North East Atlantic regions differ in oceanographic and climatic processes, human impacts, cultural heritage, spatial scales and heterogeneity and size of habitats and populations, that condition the nature of the fisheries (Smith and Garcia, 2014). Therefore, any proposal to improve management strategies should consider other complementary actions, especially taking into account that local, small-scale, coastal, artisanal fisheries constitute an important component of the idiosyncrasy of Mediterranean fisheries. Neither should it be forgotten that an important contribution of this fishing activity is developed in coastal lagoons where stock dynamics and the characteristics of the fishing gears used are difficult to incorporate in traditional approaches to fishing management (Pérez-Ruzafa and Marcos, 2012).

One aspect not explicitly considered in the above mentioned reviews (Vasilakopoulos et al., 2014; Cardinale and Scarcella, 2017) and that should be taken into account is that, after the failure of traditional fisheries management measures (Waters, 1991), marine reserves have been strongly advocated as an ideal tool for the management of coastal fisheries (Plan Development Team, 1990; Roberts and Polunin, 1991; Dugan and Davies, 1993; Agardy, 1994; Gerber et al., 2002). Indeed, analysis of global trends in world fisheries points to the urgency of implementing non-conventional approaches, including the establishment of marine reserves, which enabled the apparent sustainability of preindustrial fisheries (Pauly et al., 2005). As a result, a large number of marine protected areas (MPAs) have been established in recent decades throughout the world, including the EU (Jones et al., 1993; Lubchenco et al., 2003; Fenberg et al., 2012; Devillers et al., 2015; Batista and Cabral, 2016). Beyond this, "the establishment of MPAs is an important contribution to the achievement of a good marine environmental status" under the European Marine Strategy Framework Directive (Directive 2008/56/EC) and are considered an affordable way to mitigate and promote adaptation to climate change (Roberts et al., 2017).

Formally, the terms marine protected area (MPA) and marine reserve are not exactly synonymous (Table 1) and, in fact, there are a large number of conservation entities, with different levels of protection, permitted uses, and management measures.

As a fisheries management tool, a marine reserve is a notake zone where it is forbidden to extract organisms in any way, except, in some cases, when required for scientific monitoring (Roberts and Hawkins, 2000; Halpern and Warner, 2002).

For its part, the term MPA is a more general concept applied to defined geographical areas, which are recognized, and managed, by law or other effective regulations, to preserve marine ecosystems and their associated ecosystem services and attributes, including biodiversity, species populations, cultural values, or economic resources such as fisheries production (Dudley, 2008; Thomas et al., 2014). Such areas can take a high variety of forms and designs (Planes et al., 2006), denominations (http://oceanservice.noaa.gov/facts/mpa. html), accepted uses (Mazor et al., 2014b) and management objectives at all levels of government and spatial scales (Portman et al., 2012; Giakoumi et al., 2013). In the UK, for example, MPAs include Special Areas of Conservation according to the EU Birds and Habitats Directives, Marine Nature Reserves' and Sites of Special Scientific Interest, the main aim of most of them being conservation of biodiversity, while very few are designed for managing fisheries (Gubbay, 2006). Indeed, throughout the world, the vast majority of MPAs allow fishing and extractive activities, as well as other commercial or recreational practices such as boating or scuba-diving (Thomas et al., 2014).

Despite this multiciplity of objectives, MPAs are viewed in Europe and worldwide as the best way to protect fishing resources and conserve marine biodiversity (Gaines et al., 2010a; Costello and Ballantine, 2015; Lubchenco and Grorud-Colvert, 2015). Many European MPAs have a common objective to keep harvested populations below the overfishing threshold, while maximizing sustainable yields (Fenberg et al., 2012; European Environment Agency, 2015), a second objective being to prevent the loss of biodiversity due to human erosion (Pauly et al., 2002, 2005).

The expected benefits of MPAs include preserving the spawners and the natural size and age structure of populations, maintaining assemblage structure and ecosystem equilibrium, maintaining genetic diversity and facilitating the recovery of stocks in over-exploited areas through the exportation of eggs and larvae to neighboring areas. At the same time they allow the development of research in non-impacted ecosystems that can be used as control areas in experimental sampling designs and as reference conditions for environmental impact and ecological status assessments (García-Charton et al., 2008; Wood et al., 2008; Lester et al., 2009; Fenberg et al., 2012).

Here (1) we provide a comprehensive review of the effects of MPAs as a fisheries management tool, (2) we highlight the differences in their use and expected benefits between Northeastern and Southern-Mediterranean- Europe, and (3) we apply the classical holistic view of ecological succession to the 
TABLE 1 | Definitions of the most common existing figures and terminology for the protection of marine areas.

\begin{tabular}{|c|c|}
\hline Key term & Definitions \\
\hline Marine Protected Area & $\begin{array}{l}\text { The IUCN, after the more specific initial definition (IUCN, 1988, 1994), actually aligns the meaning of MPA with the definition of a "protected } \\
\text { area" as "a clearly defined geographical space, recognized, dedicated and managed, through legal or other effective means, to achieve the } \\
\text { long-term conservation of nature with associated ecosystem services and cultural values" (Dudley, 2008). } \\
\text { More concretely, Marine Protected Areas (MPAs) are "any marine area set aside under legislation to protect marine values". Such values } \\
\text { include conservation, commercial, species enhancement, scientific importance, historic, recreational, scenery or aesthetics, cultural, etc. (Day } \\
\text { and Roff, 2000). } \\
\text { "They come in a variety of forms and denominations, as marine sanctuaries, marine reserves, fully protected marine areas, no take zones, } \\
\text { estuarine research reserves, ocean or marine parks, or marine wildlife refuges, which may have different implications according to the country } \\
\text { in which they are established" (FAO, 2011; http://oceanservice.noaa.gov/facts/mpa.html). }\end{array}$ \\
\hline
\end{tabular}

Multiple-use MPA

"MPAs typically comprise fluid and dynamic marine ecosystems, have a high diversity of habitats and species within an area and contain highly migratory marine species. This complexity often dictates the need for multiple objectives and complex management schemes" (Dudley, 2008). In the marine environment, this is particularly important and zoning is recommended in the IUCN best practice guidelines on MPAs as the best way of ensuring protection and managing multiple-use protected areas (Kelleher, 1999).

Marine Reserve "Marine reserves are a specific type of MPA that achieves the preservation of the biodiversity and other values in a strictly protected area, where activities that remove animals and plants or alter habitats are prohibited, except as needed for scientific monitoring. They have become an important tool for both marine biodiversity protection and fisheries management" (Roberts and Hawkins, 2000; Dudley, 2008; http://www. protectplanetocean.org/introduction).

A marine reserve or "no take" MPA is a highly protected type of MPA where removing or destroying natural or cultural resources is prohibited. (NOAA access 06/06/2017 http://marineprotectedareas.noaa.gov/aboutmpas/).

"They usually allow human access and even some uses, but prohibit the extraction or significant destruction of natural and cultural resources. Also coincide with the no-take level of protection established in some whole or multiple-use MPAs, and so they are often called a "no-take" MPA" (http://marineprotectedareas.noaa.gov/pdf/helpful-resources/factsheets/mpa_classification_may2011.pdf; http://www. protectplanetocean.org/collections/introduction/introbox/reserves/introduction-item.html).

No-Take zone $\quad$ "This protection category is not compatible with any removal of marine species or modification, extraction or collection of marine resources, with scarce exceptions such as scientific research. Human visitation is limited, to ensure preservation of the conservation values. Setting aside strictly protected areas in the marine environment is of fundamental importance, particularly to protect fish breeding and spawning areas and to provide scientific baseline areas that are as undisturbed as possible. They may comprise a whole MPA or frequently be a separate zone within a multiple-use MPA, seen as "cores" surrounded by other suitably protected areas" (Dudley, 2008).

\begin{tabular}{|c|c|}
\hline Buffer zone & $\begin{array}{l}\text { "Areas around a core protected zone that are managed to help maintain protected area values" (Dudley, 2008). They preserve the entire } \\
\text { protected zone from potentially damaging external influences and are essentially transitional areas where appropriate economic activities are } \\
\text { permitted and where sustainable resource management practices can be developed (Bennett and Mulongoy, 2006; Dudley, 2008). }\end{array}$ \\
\hline Fish Box & $\begin{array}{l}\text { "Some sites, such as fish spawning aggregation areas or pelagic migratory routes, are critically important and the species concerned are } \\
\text { extremely vulnerable at specific and predictable times of the year, while for the rest of the year they do not need any greater management than } \\
\text { surrounding areas. The EU has encouraged the establishment of such conservation "boxes" or "fishery closure areas" within which seasonal, } \\
\text { fulltime, temporary or permanent controls are placed on fishing methods and/or access" (Dudley, 2008; http://www.protectplanetocean.org/ } \\
\text { introduction/introbox/glossary/glossary/introduction-item.html\#marres). }\end{array}$ \\
\hline
\end{tabular}

Network of MPAs "Set of discrete MPAs within a region or ecosystem that are connected through complementary purposes and synergistic protections, at
various spatial scales, and with a range of protection levels designed to meet objectives that a single reserve cannot achieve. A network of
MPAs could focus on ecosystem processes, certain individual marine species, or cultural resources. For example, an ecological network of
MPAs could be connected through dispersal of reproductive stages or movement of juveniles and adults" (IUCN-WCPA, 2008; http://www.
protectplanetocean.org/introduction/introbox/glossary/glossary/introduction-item.html\#marres). Connectivity and its scales play here a
relevant role.

functioning of fisheries closures and no-use areas, in order to put light into this debate.

\section{A POWERFUL MANAGEMENT TOOL FOR BIODIVERSITY CONSERVATION}

The effects of protection on fish structure inside reserves have been demonstrated in numerous studies (e.g., McClanahan and Mangi, 2000; Claudet et al., 2008, 2010; García-Charton et al., 2008; Lester et al., 2009; Guidetti et al., 2014; Sciberras et al., 2015), although there are still several aspects that need confirmation and further efforts must be made to understand the complex mechanisms and processes that clearly produce positive effects in some cases and negative or neutral effects in others (Gaines et al., 2010a; D'agata et al., 2016; Gill et al., 2017). Basically, MPAs are expected to protect critical spawning stock biomass of species from fishery-related depletion (Bell, 1983; García-Charton et al., 2004; Claudet et al., 2006), so that they recover and maintain a natural size and age structure in the populations, hence maximizing potential fecundity, allowing biomass exportation from core to regulated areas (Reñones et al., 1999; Goñi et al., 2003; Brito et al., 2006; Harmelin-Vivien et al., 2007; Dimech et al., 2008; Hackradt et al., 2014; Di Lorenzo et al., 
2016). They also reestablish ecological interactions (Guidetti, 2006a,b) and preserve biological diversity at a regional scale (but see Klein et al., 2015) at all levels_-specific, habitat/seascape, and also genetic diversity and populations structure (Pérez-Ruzafa et al., 2006) - , allowing the force of natural selection to operate.

These effects can take place in a relatively short time. In a review of 80 reserves, Halpern and Warner (2002) found that most assemblage descriptors, such as diversity, density, average organism size, and biomass inside the reserves, reach levels comparable to control areas within the first 1-3 years and are maintained in reserves for up to 40 years. Other empirical studies show that the time taken to detect the first direct effects on target species is around 5 years, while the detection of indirect effects on other taxa takes 10-15 years (Babcock et al., 2010) or more (Claudet et al., 2008), a significantly longer time but still short enough to be perceived at the scale of human perception of changes, and within the 5-20 years time-horizons used in costbenefit analysis or community planning (Tonn et al., 2006; Hunt and Taylor, 2009; Pahl et al., 2014).

\section{MPAS AS FISHERIES MANAGEMENT TOOL}

The interest of MPAs as fishery management tool lies mostly on their potential to improve artisanal fisheries of high-value species in surrounding fishing grounds (Kerwath et al., 2013; Di Franco et al., 2016; Lloret et al., 2017). At the same time, they intend to favor the economic development of the area through the establishment of services related to tourism and diving activities providing an alternative source of inputs also for fishermen (Angulo-Valdés and Hatcher, 2010; Rees et al., 2015; Pascual et al., 2016). The key question for fisheries management is whether MPAs are effective only inside the protected area or whether they are also useful for maintaining productivity in the surrounding exploited grounds.

\section{MECHANISMS OF EXPORTATION}

Marine fish dispersal that would benefit fisheries in the vicinity of an MPA may occur via several mechanisms: egg and larval dispersal (Cowen et al., 2000; Abesamis et al., 2016, 2017), the trophic or reproductive migrations of adults (Green et al., 2015), nomadic or ontogenetic movements (Grüss et al., 2011), and, density-independent, home-range movements by individuals across reserve boundaries and home-range relocation because of density-dependent factors (Rakitin and Kramer, 1996; Russ and Alcala, 1996; Kramer and Chapman, 1999; Pérez-Ruzafa et al., 2008). Although, all these mechanisms potentially increase the catch in surrounding areas, and hence likely benefit fisheries by helping to recover and maintain target populations, full benefits of MPAs would require protecting also other mechanisms determining reproductive success, such as those necessitating essential habitats (Elliott et al., 2016)-e.g., spawning grounds (Erisman et al., 2015; Sadovy de Mitcheson, 2016) and recruitment areas (Cheminée et al., 2017). On the other hand, some authors differentiate "ecological spillover" (i.e., the net export of juvenile, subadult and adult biomass from MPAs outwardly driven by density-dependent processes) from "fishery spillover" (i.e., the proportion of this biomass that can be fished, taking into account regulations and accessibility; Di Lorenzo et al., 2016).

Although, some of these processes are difficult to demonstrate in the field (Harmelin-Vivien et al., 2008; Lester et al., 2009; Di Lorenzo et al., 2016), the ability of MPAs to improve adjacent fisheries has also been related to indirect evidence, such as spatial redistribution of fishing effort (Murawski et al., 2005; Goñi et al., 2008; Stelzenmüller et al., 2008; Cabral et al., 2016) and the direct recording of catches by commercial fishing (Vandeperre et al., 2011).

In the last decade, modeling approaches have also analyzed the exportation of individuals on the basis of diffusive processes dependent on density gradients (Gerber et al., 2003; Neubert, 2003; Kellner et al., 2007; Pérez-Ruzafa et al., 2008), which is consistent with observed patterns in fish abundance and fishing effort distribution. Other models incorporate movement patterns-migration, ontogenetic movements, etc. (e.g., as those reviewed by Grüss, 2014).

Protection also produces a rapid response in fishermen's behavior. From the first year, fishing effort and "catch per unit effort" (CPUE) tend to concentrate at the boundaries of the MPAs and gradually increase with time. Using a metaanalytical approach to investigate the effects of protection on adjacent fisheries based on 28 data sets from seven southern European MPAs, Vandeperre et al. (2011) found clear effects on the surrounding fisheries, both as regards the CPUE of the target species and, especially, on the CPUE of the marketable catch.

These effects mainly depend on the time of protection and on the size of the no-take area. The CPUE of both the marketable catch and target species increased gradually by $2-4 \%$ per year over a long period (at least 30 years). On average, the protected areas provided catches about 2.4 higher than those from the non-protected areas (Vandeperre et al., 2006).

Despite this quick response, the effects can be hidden by fishermen's behavior. Up to $75 \%$ of fishing gears can be deployed within $1 \mathrm{~km}$ of the MPA (Murawski et al., 2004, 2005) and most catches in other studies were concentrated within $10 \mathrm{~km}$ from the reserve boundaries (Kellner et al., 2007; Goñi et al., 2008; Stelzenmüller et al., 2008). The rapid concentration of fishing effort near the boundaries of the reserve causes a rapid fall in CPUE (Pérez-Ruzafa et al., 2008; Vandeperre et al., 2011), so that a successive increase/decrease/ recover of yields ultimately leads to pre-reserve levels being exceeded (Hopf et al., 2016). However, in very small MPAs or when the protected area is located peripherally within the metapopulation, the recovery time runs from several years to decades and reserves are sometimes unable to support the increased mortality so that the metapopulation collapses (Hopf et al., 2016).

Although, some empirical studies showed that the spatial response of fishing boats to the implementation of an MPA greatly depends on the local particularities (fishing modalities, spatial distribution of habitats, prevailing winds, currents regime, etc.), precluding an oversimplified assumption about redistribution of fishing effort (Cabral et al., 2016), usually, the relocation of fishing effort leads to a "fishing the line" harvesting tactic (Kellner et al., 2007). 


\section{WHO BENEFITS MOST FROM MPAS?}

MPAs are not only a good fisheries management tool. The economic revenues of MPAs have been claimed as being beneficial for all stakeholder groups, especially in southern European MPAs, where the demand for diving activities increases exponentially and fishing and scuba-diving are the main coexisting uses (Roncin et al., 2008; Fenberg et al., 2012; Sala et al., 2013). A broad socio-economic field survey covering 12 case studies in southern Europe showed a variety of situations, from MPAs where commercial fishing is the major economic stake (up to $88 \%$ of total incomes locally generated by fishing and diving), to MPAs where recreational activities have a dominant economic role (where incomes generated by commercial fishing can amount to $<5 \%$ of the money generated by scuba diving; Roncin et al., 2008). In general, recreational diving is prevailing in coastal areas, while fishing is more associated with MPAs far from the coast, where diving activities are difficult (Roncin et al., 2008). On average, the amount of locally generated income by fishing and diving in the southern European MPAs studied by Roncin et al. (2008) represented at least 2.3 times the management costs.

According to Mangi and Austen (2008), there is a high level of satisfaction among users of marine reserves. However, most stakeholders consider MPAs that have been established for longer periods of time offer greater benefits for conservation than fisheries and that such conservation benefits gradually increase with the time of protected area management. Of note is the fact that the main reasons given by divers to justify the use of MPAs as diving sites are fish abundance and the presence of some spectacular or "emblematic" species (e.g., grouper in the Mediterranean). However, the evaluation of MPAs as areas to benefit fisheries decreased with the time an area is protected due to a gradual change in fishermen's perception.

The belief amongst fishermen in the potential of MPAs to deliver fisheries objectives declines with time, coinciding with the time taken by the relocation process of fishing effort to reach a "fishing the line" equilibrium. After this time, all fishermen in a gradient from the MPA boundary would attach the same CPUE, explaining why after this time the perception of fishermen could become more neutral, while the perception of benefits for divers and diving operators is still increasing.

\section{FISH BOX VS. MPAS}

Despite the benefits provided by marine reserves, after more than 25 years of research into their effectiveness, fishery managers question European scientists about the apparent failure of north European MPAs to reach the expected fisheries objectives (Pastoors et al., 2000; Daw and Gray, 2005; Beare et al., 2010). Moreover, if we compare them with Mediterranean MPAs, which are generally viewed by researchers and, more importantly, by users as being successful (Guidetti et al., 2014), the question arises as to the possible causes of such divergence.

In classical fisheries science, it is increasingly assumed that the concept of MSY, as a reference for the catch rate, should be reinterpreted as an upper limit rather than a management target, by replacing the traditional goal of maximizing the catch by that of maximizing economic profit or even minimizing the impact of fishing (Froese et al., 2011, 2016a,b), although this is not being implemented yet in national and EU fishing policies (Marchal et al., 2016). This requires the introduction of a range of management tools that permits an overall reduction in exploitation rates. Implementing the best management tools may depend on the local context, but there is an overall view that a combination of traditional fisheries management measures (catch quotas, closed seasons, community management) coupled to strategically placed fishing closures, ocean zoning, increased selectivity of fishing gear, and economic incentives, holds much promise for the restoration of marine fisheries and ecosystems (Worm et al., 2009; Froese et al., 2015). In theory, except for sedentary species, for which reserves have important advantages, the management of fisheries through setting up reserves and management through effort control may produce identical yields under a reasonable set of simplifying assumptions corresponding to a broad range of biological conditions (Hastings and Botsford, 1999).

In Europe, MPA design differs between Atlantic and Mediterranean areas (Figure 1). Northern MPAs (the so-called fish boxes or fisheries closures; Pastoors et al., 2000) are generally very large (hundreds of thousands of hectares), and are intended to protect one or a few target or by-catch species (e.g., plaice, sole, cod, herring, sprat, haddock). In this case, fisheries regulations typically consist of traditional fishing regulations, banning specific gears, and/or reducing the fishing effort within the whole closed area. For their part, Mediterranean MPAs (Planes et al., 2006; Fenberg et al., 2012) are usually small (hundreds of hectares or less; Gabrié et al., 2012; Portman et al., 2012), and are in general located in areas that are biologically unique, because of the occurrence of remarkably diverse and/or complex habitats; they always include a core marine reserve, a no-use or no-take area (i.e., where all human activity is banned or any type of fishing is absolutely prohibited), and they are often bounded by a buffer area, where some fishing activity is allowed and strongly regulated by traditional approaches. Although, the difference in total size arises as the immediate option to explain differences between Northern and Southern European MPAs, empirical evidence is less clear on this: while some studies argue for large MPAs to ensure their success, other recommend smaller MPAs (Claudet et al., 2008; Fletcher et al., 2015; Hughes et al., 2016).

The proponents of an ecosystem approach to fisheries management are still struggling with finding practical ways of application (Fulton et al., 2014; Jennings et al., 2014; Link and Browman, 2014; Berg et al., 2015; Coll et al., 2015; Long et al., 2015; Patrick and Link, 2015). Most initiatives so far are based on the notion that less diverse communities are less productive (Gamfeldt and Hillebrand, 2008; Tilman et al., 2014; Strong et al., 2015). But, as Margalef (1997) pointed out [embracing Odum (1969) holistic view of succession], decreasing productivity to biomass ratios is the most likely driver of ecosystem growth when moving from early to more mature stages, once an initial "squandering" phase has been surpassed (Figure 2). This pattern generally does not take into account the mechanisms determining the actual sequence of replacement and the rate 

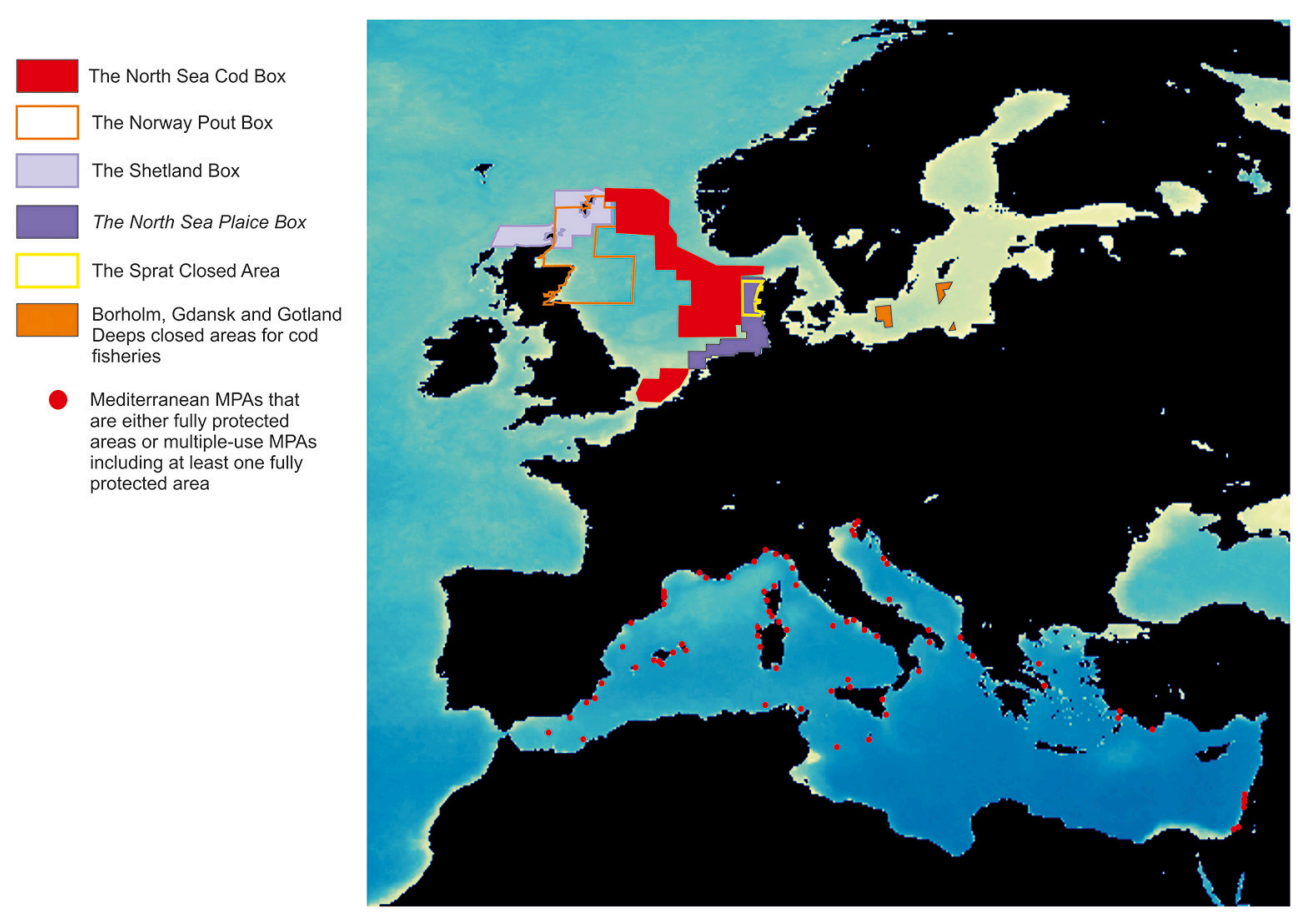

FIGURE 1 | Main fish closures in the North and Baltic Seas (Sørensen, 2006) and distribution of present Mediterranean MPAs in April 2017 (MAPAMED, 2017 ; http:// www.medpan.org/en/mapamed). Base map corresponds to averaged maximums of Chlorophyll a for the period 2003-2010 from satellite data.

of the same (Valiela, 1995). In this context, the objectives of fishery measures of maintaining a MSY, which are those of most Northern MPAs, can only be attained in a relatively early phase of succession, when net production is maximized (Figure 2). The position of this stage in the succession will vary depending on the life cycle, trophic level or life-history strategy ( $r$ vs. $K$ ) (or, more generally, the average trophic level) of the species forming the catch. But this situation is achieved in a narrow successional fringe-, so that overexploitation will lead to a decrease in productivity, although the same occurs if regulatory measures move the ecosystem excessively toward more mature stages. The latter situation leads to the apparent paradox that, contrary to expectations, fishing limitations reduce fishing yields in fish boxes when more harvested (i.e., stressed by fishing disturbance, and then kept at a younger successional stage) are compared with partially protected areas, making the failure of protection measures more probable.

By contrast, Mediterranean MPAs enhance fishing yields through spillover from core no-take areas to neighboring, regulated and unprotected areas (Gell and Roberts, 2003; Tudela et al., 2005; Stelzenmüller et al., 2008) after the protected ecosystem is left to reach a state of maturity (Figure 2). A late successional stage is characterized by more species, longer-lived organisms, and complex food webs with a higher number of trophic levels. This mature stage is inevitable, as succession is a process of self-organization (Fath et al., 2004). Empirical studies in Mediterranean MPAs (García-Charton et al., 2004; Tudela et al., 2005; Coll et al., 2013; García-Rubies et al., 2013; Guidetti et al., 2014) showed how fish communities undergo a huge increase in target biomass-usually piscivore species within core marine reserve areas, and restoring a more "natural" community structure, provided that they are well enforced (Guidetti et al., 2008; Di Franco et al., 2016). All this leads to the general view that Mediterranean MPAs are almost always successful in achieving the planned objectives.

The above holistic ecological considerations lead us to advocate that an optimal management strategy for designing an MPA (also in the Northern Atlantic) to protect biodiversity and sustain fishing yields would be a combination of a network of no-use marine reserve areas (close to their mature state) with fish boxes (maintained by fishing disturbance in a relatively early successional stage, where productivity is higher), under a multi-zoning scheme.

\section{OPTIMUM DESIGN: MAXIMIZING CONSERVATION, EXPORTATION AND MAINTENANCE COSTS}

\section{Zonation in an MPA}

There is no one design for an MPA. Apart from the size and form, some MPAs consider only a no-take zone or marine reserve where no human activity except scientific surveys is forbidden, others also include one or several buffer zones with different relative sizes with respect to the core reserve where some gears and different degrees of regulated fishing is permitted, and other buffer zones are entirely regulated like the fish box (Planes et al., 2006; Horta e Costa et al., 2016). 


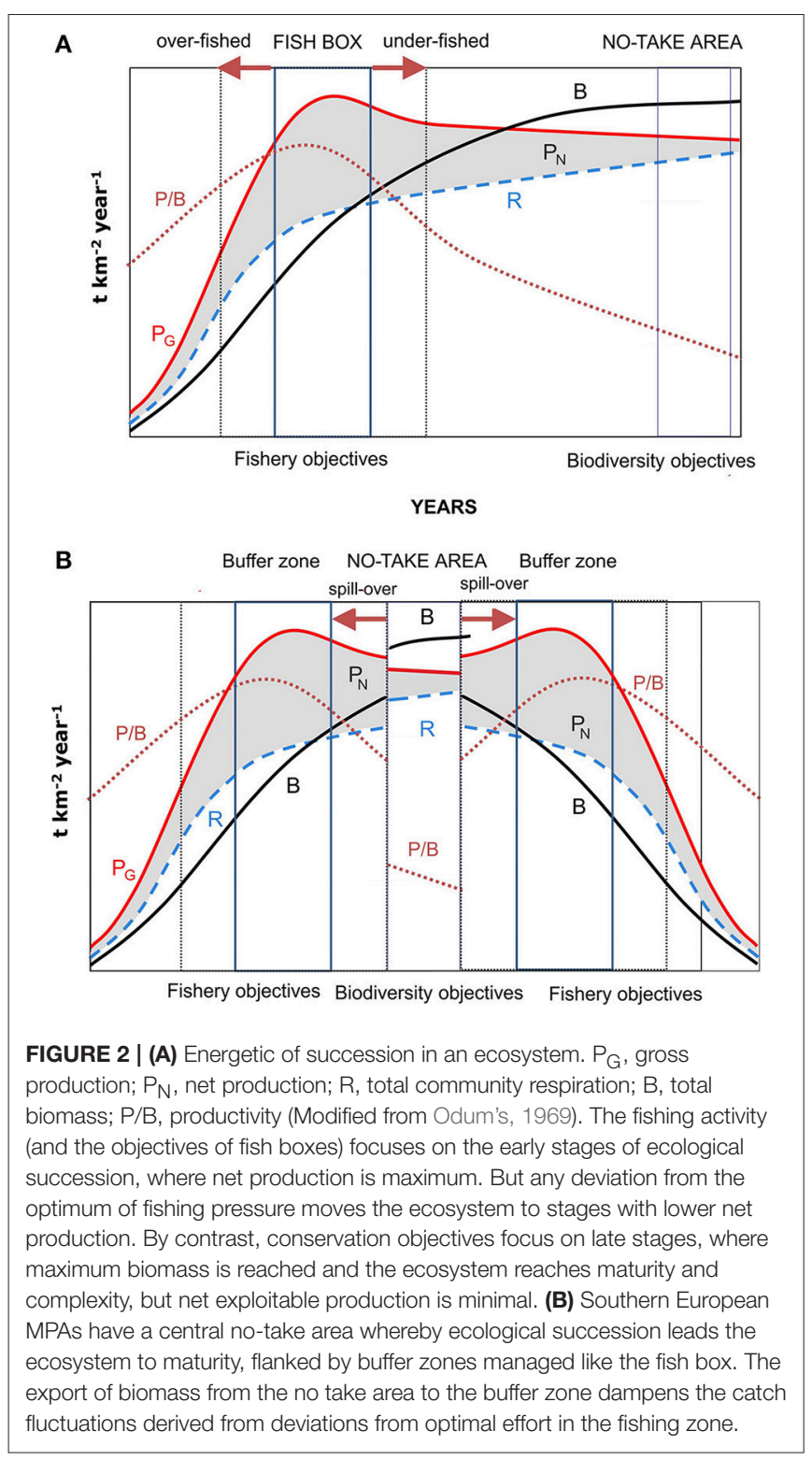

The design affects MPA effectiveness and, contrary to what might be expected, larger buffer areas seem to negatively affect both ecological aspects and fishing yields in the surrounding areas (Claudet et al., 2008; Vandeperre et al., 2011). Although, no explanation has been proposed for this, it could be related to the fact that the spill-over spatial scale is much reduced. Enlarging the buffer area implies that, although subjected to fishing regulations, the real effects of protection due to the no take zone became diluted in a longer gradient, making differences between the buffer and the free fishing areas less pronounced than with smaller buffer zones.

\section{How Big Should an MPA Be? Size Do Matter But...}

Meta-analyses performed on 58 datasets from 19 Southern European MPAs showed that the size of the no-take zone and time of protection are the main factors determining the effectiveness of an MPA for preserving the abundance and size structure of fish assemblages (Claudet et al., 2008). Similar conclusions are reached when the effects on fisheries are analyzed considering CPUE data (Vandeperre et al., 2011).

Pérez-Ruzafa et al. (2008), using a modeling approach, showed that medium size to large marine reserves $(>600 \mathrm{ha}$ ) are to be preferred to small ones, both to maximize the protection of fish populations abundance and to improve the exportation of biomass across the marine reserve boundaries (Pérez-Ruzafa et al., 2008), thus agreeing with empirical data. Larger reserves attain between 80 and $100 \%$ of the carrying capacity in the first 5 years after protection depending on fish mobility or fishing effort in the surrounding area. However, reserves smaller than $500 \mathrm{~m}$ in radius have difficulties in attaining $50 \%$ of the carrying capacity, especially in the case of fishes of high mobility and subject to high fishing effort in neighboring areas (Pérez-Ruzafa et al., 2008). Furthermore, improvement in maintaining higher populations abundance or in exporting individuals increase very slowly for reserves larger than 1,500 ha (Pérez-Ruzafa et al., 2008).

The spatial scale of influence of a marine reserve is lower than might be expected. Some reviews of demersal fish and invertebrates suggest adult neighborhood sizes ranging from a few kilometres to 10 to $100 \mathrm{~km}$, and for larval dispersal, of 10 to $100 \mathrm{~km}$ for invertebrates and 50 to $200 \mathrm{~km}$ for fish (Palumbi, 2004). Recent studies (e.g., D’Aloia et al., 2015; Green et al., 2015) reports even shorter average dispersal distance $(<5-15 \mathrm{~km})$ and highlight that self-recruitment is a common phenomenon. Field studies based on underwater visual censuses have shown that the gradient in fish abundance due to spill-over through the reserve boundary is only detectable at small spatial scales (a few 100 m; Harmelin-Vivien et al., 2008). In modeling approaches, the effect of the flux of individuals from the reserve to the fished areas is evident at $<5-10 \mathrm{~km}$ from the boundary (Pérez-Ruzafa et al., 2008). In the case of larvae, Jessopp and McAllen (2007) found limited exchange between reserve and non-reserve areas at a relatively small spatial scale $(<3 \mathrm{~km})$ depending on the hydrographic and geomorphologic characteristics of the sites. In the case of models for larval exportation, changes in yield biomass during the first year are evident within $14 \mathrm{~km}$ of the reserve (Hopf et al., 2016).

Furthermore, although size does matter, any improvement in populations abundance or in exporting individuals decreases very quickly for reserves larger than 1,500 ha (Pérez-Ruzafa et al., 2008). Even, although strongly contested by other authors (Hughes et al., 2016), the usefulness of excessively large reserves has been questioned for improving fishery performance (Fletcher et al., 2015).

At the same time, the effectiveness of a MPA is highly dependent on users' compliance with regulations, and noncompliance is often the rule rather than the exception (Arias and Sutton, 2013; Bergseth et al., 2015, 2017; Arias et al., 2016). This makes proper surveillance and enforcement to prevent or reduce poaching to a minimum are essential in any marine reserve (Davis et al., 2004; McCauley et al., 2016). Enforcement constitutes one of the main costs in the maintenance of an MPA, something that is especially evident in MPAs far from 
land and in the case of recently proposed and declared megaparks of more than $250,000 \mathrm{~km}^{2}$ for which the development and use of relatively expensive next-generation enforcement, such as satellite and drone based patrols will be necessary (McCauley, 2014; Arias et al., 2016; McCauley et al., 2016).

Therefore, it is clear that for any marine conservation plan to be feasible and efficient it is necessary to include the costs derived both from its implementation and maintenance (Mazor et al., 2014a). The socio-economic analyses performed by Alban et al. (2008), which considered all the costs involved in MPA management for the 12 case studies considered by Roncin et al. (2008), showed that, as could be expected, total management costs increase with reserve size, but total cost per ha is minimum for integral marine reserves of between 600 and 1,500 ha $(1,400-$ $2,200 \mathrm{~m}$ radius).

Taking into account all these ecological, fishing and economic considerations, it may be concluded that the optimum size for marine reserves to improve conservation and fishing yields at minimum cost, would be between 600 and 1,500 ha.

\section{Designing Networks of MPAs}

It has been estimated that, to maintain biodiversity, at least a 20 $30 \%$ of the ocean should be protected (Morgan, 2014; Pressey et al., 2014). At present, only about $3.6 \%$ of the ocean has some kind of protection, and just $1.6 \%$ is covered by strongly or fully protected (i.e., "no-take" reserves; Lubchenco and GrorudColvert, 2015); furthermore, only $2.1 \%$ of existing MPAs are actively managed (Sala et al., 2016), i.e., more than 'paper parks'. Increasing coastal area or coastal lengths under protection can be done increasing the size of marine reserves. However, as mentioned above very large marine reserves can be effective for preserving biodiversity and can have higher resilience, but are controversial as a fisheries management tool, while surveillance costs increase exponentially. A good alternative would be to establish MPA networks (Gaines et al., 2010b; Grorud-Colvert et al., 2014; Bode et al., 2016). After the results highlighted above, a network of marine reserves of around 600 ha each separated by tens of kilometres would optimize the balance between conservation efficiency and maintenance costs and have a synergistic effect on the export of biomass in fishing areas between reserves. In addition, the capacity increases and recovery rates of regional, well interconnected stocks after protection is even faster than in individual stocks, with some studies reporting that fish densities recovered in 1.5-2 years after rezoning (Russ et al., 2008).

One important aspect to consider in designing reserve networks is connectivity. Ensuring that reserve populations are connected and maintain genetic fluxes between each other and with non-reserve populations through larval or adult dispersal allows for recovery from disturbance and is a key aspect in resilience (Almany et al., 2009; Calò et al., 2013). However, it is also necessary to optimize trade-offs between connectivity and representation objectives, including species and habitat diversity, while minimizing the risk that multiple reserves will be impacted by catastrophic events (Almany et al., 2009). Spatio-temporal heterogeneity can play an important role in the emergence of homeostatic mechanisms of complex coastal ecosystems (Pérez-Ruzafa et al., 2005) and the introduction of restrictions to connectivity can develop complex structures that enhance biodiversity at genetic and taxonomic levels (PérezRuzafa, 2015).

\section{CONCLUSIONS}

In just over a decade, and although many aspects remain to be investigated, much has been accomplished since the first proposals for the creation of marine reserve networks, from the uncertainties that existed (Roberts, 2000; Roberts et al., 2001; Botsford et al., 2003), to our present knowledge of how they function and the effects they have on ecological processes, fisheries and the economic activity.

The appropiate design of MPA networks allows conservation and fishery objectives to be coupled and can provide ecological and recreational services of value (Roberts et al., 2003).

Despite the fact that fisheries in both North East Atlantic and the Mediterranean Sea are governed by the European CFP, great discrepancies in performance have been observed, with recent considerable improvements in stock status in the North East Atlantic being matched by a rapidly deteriorating situation in the Mediterranean region. The control of fishing effort combined with specific technical measures, such as gear regulation, the establishment of a minimum conservation reference size and selective closure of areas and seasons, is the main management strategy adopted by Mediterranean EU countries, while Total Allowable Catches is the major regulatory mechanism in the North East Atlantic (Cardinale and Scarcella, 2017). However, these analyses focus on species fished by trawling generally at greater depths than is usual for MPAs and do not consider local shallow water fisheries, which are the most traditional in the Mediterranean.

By contrast, Mediterranean MPAs work not only by increasing fishing yields, but also by promoting the economy based on recreational diving, tourism, and meeting the objectives of biodiversity conservation, while the Fish Box of northern Europe does not reah spectations.

The holistic ecological considerations discussed above lead us to advocate that an optimal management strategy for designing an MPA (also in the Northern Atlantic) to protect biodiversity and sustain fishing yields consists of combining a network of no-use areas (close to their mature state) with fish boxes (buffer zone maintained by fishing disturbance in a relatively early successional stage, where productivity is higher), under a multizoning scheme. In this framework, the importance of no-use areas for fisheries is based on several observations:

- They preserve biological diversity at regional scale, at all levels-specific, habitat/seascape, and also genetic diversity and the structure of populations (Pérez-Ruzafa et al., 2006), allowing natural selection to operate.

- They permit the natural variability of the system to be differentiated from the effects of regulation and to be integrated in appropriate sampling schemes as controls.

- They maintain the natural size and age structure of the populations, hence maximizing potential fecundity, allowing 
biomass export to occur from core to regulated areas, dampening the fluctuations derived from deviations from the optimal effort in the fishing zone.

Proper surveillance and enforcement, which prevents or reduces poaching to a minimum, is essential in any marine reserve to ensure its proper functioning and to introduce corrective management measures. At this point, fishermen themselves, as one of the main beneficiaries of the proper functioning of marine reserves, can play an important role in conservation and sustainable practices in a co-managed framework (Claudet and Guidetti, 2010; Hogg et al., 2013).

To evaluate the degree of success of such multi-zone MPAs, we need a suite of fishery and ecological management indicators for both fish boxes and no-use areas. Such indicators must provide a key for convergence of the recovering community in fish boxes to be examined with respect to a mature stage in a given envelope of environmental conditions, using the no-use areas as reference points. Several holistic indicators are usable (Greenstreet and Rogers, 2006; Salas et al., 2006; Shin and Shannon, 2010; Teixeira et al., 2016), including diversity measures, thermodynamicallyderived functions (Jørgensen and Mejer, 1979), tropho-dynamic indexes (Tudela et al., 2005), and others more or less specific for exploited marine ecosystems (Shin et al., 2010). Research actions are urgently needed to define those suites of indicators capable of establishing the appropriate reference levels to guide management strategies to recover the increasingly collapsed fish populations in our seas (Rossberg et al., 2017).

We advocate that the optimum size of no-take zones would range between 600 and 1,500 ha, while the size of each zone

\section{REFERENCES}

Abesamis, R. A., Saenz-Agudelo, P., Berumen, M. L., Bode, M., Jadloc, C. R. L., Solera, L. A., et al. (2017). Reef-fish larval dispersal patterns validate no-take marine reserve network connectivity that links human communities. Coral Reefs 1-11. doi: 10.1007/s00338-017-1570-0

Abesamis, R. A., Stockwell, B. L., Bernardo, L. P. C., Villanoy, C. L., and Russ, G. R. (2016). Predicting reef fish connectivity from biogeographic patterns and larval dispersal modelling to inform the development of marine reserve networks. Ecol. Indic. 66, 534-544. doi: 10.1016/j.ecolind.2016. 02.032

Agardy, T. (1994). Advances in marine conservation: the role of marine protected areas. Trends Ecol. Evol. 9, 267-270. doi: 10.1016/0169-5347(94)90297-6

Alban, F., Person, J., Roncin, N., and Boncoeur, J. (2008). Analysis of SocioEconomic Survey Results. EMPAFISH Project, Booklet n 3 . Editum, Murcia. 139. Available online at https://www.um.es/empafish/files/Deliverable\%2022. pdf

Almany, G. R., Connolly, S. R., Heath, D. D., Hogan, J. D., Jones, G. P., McCook, L. J., et al. (2009). Connectivity, biodiversity conservation and the design of marine reserve networks for coral reefs. Coral Reefs 28, 339-351. doi: 10.1007/s00338-009-0484-x

Angulo-Valdés, J. A., and Hatcher, B. G. (2010). A new typology of benefits derived from marine protected areas. Marine Policy 34, 635-644. doi: 10.1016/j.marpol.2009.12.002

Arias, A., and Sutton, S. G. (2013). Understanding recreational fishers' compliance with no-take zones in the Great Barrier Reef Marine Park. Ecol. Soc. 18:18. doi: 10.5751/ES-05872-180418

Arias, A., Pressey, R. L., Jones, R. E., Álvarez-Romero, J., and Cinner, J. E. (2016). Optimizing enforcement and compliance in offshore marine within the MPA should be scaled to maximize the size of the no-take area to the detriment of buffer zones (about half the size of the no-take area). Any further improvement should come from a network of several MPAs, taking into account that the effects on fisheries improves when the distance between MPAs is no greater than a few tens of kilometres. Such a design fully meets the objective of protecting at least a 20$30 \%$ of the coastal area to maintain biodiversity. For pelagic and offshore species, spatial scales should be expanded and larger reserves may be needed, but with the same basic design model. In these cases, surveillance becomes more expensive and new methods, including technological ones, that are effective at the lowest possible cost will have to be developed, also taking into account that international, transboundary collaboration will increase conservation efficiency (Kark et al., 2009; Jay et al., 2016).

\section{AUTHOR CONTRIBUTIONS}

All authors listed have made a substantial, direct and intellectual contribution to the work, and approved it for publication.

\section{ACKNOWLEDGMENTS}

The main ideas of this work were conceived within the EU project EMPAFISH (SSP8-006539) and will be developed during the project RESERVEBENEFIT (BiodivERsA3-2015-21 and PCIN2016-139). We would like to thank the comments of the referees who have made it possible to improve the final result of this work.

protected areas: a case study from Cocos Island, Costa Rica. Oryx 50, 18-26. doi: 10.1017/S0030605314000337

Babcock, R. C., Shears, N. T., Alcala, A. C., Barrett, N. S., Edgar, G. J., Lafferty, K. D., et al. (2010). Decadal trends in marine reserves reveal differential rates of change in direct and indirect effects. Proc. Natl. Acad. Sci. U.S.A. 107, 18256-18261. doi: 10.1073/pnas.0908012107

Batista, M. I., and Cabral, H. N. (2016). An overview of Marine Protected Areas in SW Europe: factors contributing to their management effectiveness. Ocean Coast. Manag. 132, 15-23. doi: 10.1016/j.ocecoaman.2016.07.005

Beare, D., Rijnsdorp, A., Van Kooten, T., Fock, H., Schroeder, A., Kloppman, M., et al. (2010). Study for the Revision of the Plaice Box. Final Report number C002/10. Wageningen IMARES/European Commission DG MARITIME AFFAIRS and FISHERIES.

Bell, J. D. (1983). Effects of depth and marine reserve fishing restrictions on the structure of a rocky reef fish assemblage in the northwestern MediterraneanSea. J. Appl. Ecol. 20, 357-369. doi: 10.2307/2403513

Bennett, G., and Mulongoy, K. J. (2006). Review of Experience with Ecological Networks, Corridors and Buffer Zones. Secretariat of the CBD, Technical Series no. 23, Montreal.

Berg, T., Fürhaupter, K., Teixeira, H., Uusitalo, L., and Zampoukas, N. (2015). The marine strategy framework directive and the ecosystembased approach - pitfalls and solutions. Mar. Pollut. Bull. 96, 18-28. doi: 10.1016/j.marpolbul.2015.04.050

Bergseth, B. J., Russ, G. R., and Cinner, J. E. (2015). Measuring and monitoring compliance in no-take marine reserves. Fish Fish. 16, 240-258. doi: 10.1111/faf.12051

Bergseth, B. J., Williamson, D. H., Russ, G. R., Sutton, S. G., and Cinner, J. E. (2017). A social-ecological approach to assessing and managing poaching by recreational fishers. Front. Ecol. Environ.15, 67-73. doi: 10.1002/fee.1457 
Bode, M., Williamson, D. H., Weeks, R., Jones, G. P., Almany, G. R., Harrison, H. B., et al. (2016). Planning marine reserve networks for both feature representation and demographic persistence using connectivity patterns. PLoS ONE 11:e0154272. doi: 10.1371/journal.pone.0154272

Botsford, L. W., Micheli, F., and Hastings, A. (2003). Principles for the design of marine reserves. Ecol. Appl. 13, S25-S31. doi: 10.1890/10510761(2003)013[0025:PFTDOM]2.0.CO;2

Brito, A., Barquín, J., Falcón, J. M., González, G., Clemente, S., and Hernández, J. C. (2006). Valoración "in situ” De Las Poblaciones De Especies Indicadoras Del Efecto Reserva En La Reserva Marina De La Graciosa Y Los Islotes Del Norte De Lanzarote. Viceconsejería de Pesca del Gobierno de Canarias y Universidad de La Laguna. 107.

Cabral, R. B., Gaines, S. D., Johnson, B. A., Bell, T. W., and White, C. (2016). Drivers of redistribution of fishing and non-fishing effort after the implementation of a marine protected area network. Ecol. Appl. 27, 416-428. doi: 10.1002/eap.1446

Calò, A., Félix-Hackradt, F. C., Garcia, J., Hackradt, C. W., Rocklin, D., TreviñoOtón, J., et al. (2013). A review of methods to assess connectivity and dispersal between fish populations in the Mediterranean Sea. Adv. Oceanogr. Limnol. 4, 150-175. doi: 10.1080/19475721.2013.840680

Cardinale, M. (2011). Fishery reform: most stocks secure. Nature 476:282. doi: $10.1038 / 476282 \mathrm{a}$

Cardinale, M., and Scarcella, G. (2017). Mediterranean Sea: a failure of the European fisheries management system. Front. Mar. Sci. 4:72. doi: 10.3389/fmars.2017.00072

Cheminée, A., Rider, M., Lenfant, P., Zawadzki, A., Mercière, A., Crec'hriou, R., et al. (2017). Shallow rocky nursery habitat for fish: spatial variability of juvenile fishes among this poorly protected essential habitat. Mar. Pollut. Bull. 119, 245-254. doi: 10.1016/j.marpolbul.2017.03.051

Claudet, J., and Guidetti, P. (2010). Fishermen contribute to protection of marine reserves. Nature 464, 673-673. doi: 10.1038/464673b

Claudet, J., Osenberg, C. W., Benedetti-Cecchi, L., Domenici, P., García-Charton, J. A., Pérez-Ruzafa, A., et al. (2008). Marine reserves: size and age do matter. Ecol. Let. 11, 481-489. doi: 10.1111/j.1461-0248.2008.01166.x

Claudet, J., Osenberg, C. W., Domenici, P., Badalamenti, F., Milazzo, M., Falcón, J. M., et al. (2010). Marine reserves: Fish life history and ecological traits matter. Ecol. Appl. 20, 830-839. doi: 10.1890/08-2131.1

Claudet, J., Pelletier, D., Jouvenel, J.-Y., Bachet, F., and Galzin, R. (2006). Assessing the effects of marine protected area (MPA) on a reef fish assemblage in a northwestern Mediterranean marine reserve: identifying community-based indicators. Biol. Conserv. 130, 349-369. doi: 10.1016/j.biocon.2005.12.030

Coll, J., García-Rubies, A., Morey, G., Reñones, O., Álvarez-Berastegui, D., Navarro, O., et al. (2013). Using no-take marine reserves as a tool for evaluating rocky-reef fish resources in the western Mediterranean. ICES J. Mar. Sci. 70, 578-590. doi: 10.1093/icesjms/fst025

Coll, M., Shannon, L. J., Kleisner, K. M., Juan-Jordá, M. J., Bundy, A., Akoglu, A. G., et al. (2015). Ecological indicators to capture the effects of fishing on biodiversity and conservation status of marine ecosystems. Ecol. Indic. 60, 947-962. doi: 10.1016/j.ecolind.2015.08.048

Costello, M. J., and Ballantine, B. (2015). Biodiversity conservation should focus on no-take Marine Reserves. Trends Ecol. Evol. 30, 507-509. doi: 10.1016/j.tree.2015.06.011

Cowen, R. K., Lwiza, K. M. M., Sponaugle, S., Paris, C. B., and Olson, D. B. (2000). Connectivity of marine populations: open or closed? Science 287, 857-859. doi: 10.1126/science.287.5454.857

D’Aloia, C. C., Bogdanowicz, S. M., Francis, R. K., Majoris, J. E., Harrison, R. G., and Buston, P. M. (2015). Patterns, causes, and consequences of marine larval dispersal. Proc. Natl. Acad. Sci. U.S.A. 112, 13940-13945. doi: 10.1073/pnas. 1513754112

D'agata, S., Mouillot, D., Wantiez, L., Friedlander, A. M., Kulbicki, M., and Vigliola, L. (2016). Marine reserves lag behind wilderness in the conservation of key functional roles. Nat. Commun. 7:12000. doi: 10.1038/ncomms12000

Davis, K. L. F., Russ, G. R., Williamson, D. H., and Evans, R. D. (2004). Surveillance and poaching on inshore reefs of the Great Barrier Reef Marine Park. Coast. Manage. 32, 373-387. doi: 10.1080/08920750490487223

Daw, T., and Gray, T. (2005). Fisheries science and sustainability in international policy: a study of failure in the European Union's Common Fisheries Policy. Mar. Pol. 29, 189-197. doi: 10.1016/j.marpol.2004.03.003
Day, J. C., and Roff, J. C. (2000). Planning for Representative Marine Protected Areas: a framework for Canada's oceans. Report prepared for World Wildlife Fund Canada, Toronto.

Devillers, R., Pressey, R. L., Grech, A., Kittinger, J. N., Edgar, G. J., Ward, T., et al. (2015). Reinventing residual reserves in the sea: are we favouring ease of establishment over need for protection? Aquatic Conserv. 25, 480-504. doi: 10.1002/aqc. 2445

Di Franco, A., Thiriet, P., Di Carlo, G., Dimitriadis, C., Francour, P., Gutiérrez, N. L., et al. (2016). Five key attributes can increase marine protected areas performance for small-scale fisheries management. Sci. Rep. 6:38135. doi: $10.1038 /$ srep38135

Di Lorenzo, M., Claudet, J., and Guidetti, P. (2016). Spillover from marine protected areas to adjacent fisheries has an ecological and a fishery component. J. Nat. Conserv. 32, 62-66. doi: 10.1016/j.jnc.2016.04.004

Dimech, M., Camilleri, M., Hiddink, J. G., Kaiser, M. J., Ragonese, S., and Schembri, P. J. (2008). Differences in demersal community structure and bodysize spectra within and outside the Maltese Fishery Management Zone (FMZ). Sci. Mar. 72, 669-682. doi: 10.3989/scimar.2008.72n4669

Dudley, N. (Ed.) (2008). Guidelines for Applying Protected Area Management Categories. Gland: IUCN.

Dugan, J. E., and Davies, G. E. (1993). Applications of marine refugia to coastal fisheries management. Can. J. Fish. Aquatic Sci. 50, 2029-2042. doi: 10.1139/f93-227

Elliott, S. A. M., Milligan, R. J., Heath, M. R., Turrell, W. R., and Bailey, D. M. (2016). Disentangling habitat concepts for demersal marine fish management. Oceanogr. Mar. Biol. Annu. Rev. 54, 173-191. doi: 10.1201/978131536 8597-4

Erisman, B., Heyman, W., Kobara, S., Ezer, T., Pittman, S., Aburto-Oropeza, O., et al. (2015). Fish spawning aggregations: where well-placed management actions can yield big benefits for fisheries and conservation. Fish Fish. 18, 128-144. doi: $10.1111 /$ faf.12132

European Commission (2006). Implementing Sustainability in EU Fisheries Through Maximum Sustainable Yield. COM (2006) 360 final. Brussels: European Commission.

European Environment Agency (2015). Marine Protected Areas in Europe's Seas: An Overview and Perspectives for the Future. EEA Report $\mathrm{N}^{\circ} 3 / 2015$.

FAO (2011). "Fisheries management 4. Marine protected areas and fisheries," in FAO Technical Guidelines for Responsible Fisheries $n^{\circ}$ 4, suppl. 4. (Rome: FAO), 198.

Fath, B. D., Jørgensen, S. E., Patten, B. C., and Straškraba, M. (2004). Ecosystem growth and development. BioSystems 77, 213-228. doi: 10.1016/j.biosystems.2004.06.001

Fenberg, P. B., Caselle, J., Claudet, J., Clemence, M., Gaines, S., García-Charton, J. A., et al. (2012). The science of European marine reserves: status, efficacy, and future needs. Mar. Policy 36, 1012-1021. doi: 10.1016/j.marpol.2012. 02.021

Fletcher, W. J., Kearney, R. E., Wise, B. S., and Nash, W. J. (2015). Large-scale expansion of no-take closures within the Great Barrier Reef has not enhanced fisheries production. Ecol. Appl. 25, 1187-1196. doi: 10.1890/14-1427.1

Froese, R. (2011a). Fishery reform slips through the net. Nature 475:7. doi: $10.1038 / 475007 a$

Froese, R. (2011b). Fishing at the Edge of Collapse: 27 Years of Common Fisheries Policy in Europe. Background material for Froese, R. 2011a, Fishery reform slips through the net. Nature 475, 7.

Froese, R., Branch, T. A., Proelß, A., Quaas, M., Sainsbury, K., and Zimmermann, C. (2011). Generic harvest control rules for European fisheries. Fish Fish. 12, 340-351. doi: 10.1111/j.1467-2979.2010.00387.x

Froese, R., Coro, G., Kleisner, K., and Demirel, N. (2016a). Revisiting safe biological limits in fisheries. Fish Fish. 17, 193-209. doi: 10.1111/faf.12102

Froese, R., Walters, C., Pauly, D., Winker, H., Weyl, O. L. F., Demirel, N., et al. (2015). A critique of the balanced harvesting approach to fishing. ICES J. Mar. Sci. 73, 1640-1650. doi: 10.1093/icesjms/fsv122

Froese, R., Winker, H., Gascuel, D., Sumaila, U. R., and Pauly, D. (2016b). Minimizing the impact of fishing. Fish Fish. 17, 785-802. doi: 10.1111/faf.12146

Fulton, E. A., Smith, A. D. M., Smith, D. C., and Johnson, P. (2014). An integrated approach is needed for Ecosystem Based Fisheries Management: insights from ecosystem-level management strategy evaluation. PLoS ONE 9:e84242. doi: 10.1371/journal.pone.0084242 
Gabrié, C., Lagabrielle, E., Bissery, C., Crochelet, E., Meola, B., Webster, C., et al. (2012). “Statut des Aires Marines Protégées en mer Méditerranée. MedPAN \& CAR/ASP," in MedPAN Collection. 260.

Gaines, S. D., Lester, S., Grorud-Colvert, K., Costello, C., and Pollnac, R. (2010a). Evolving science of marine reserves: new developments and emerging research frontiers. Proc. Natl. Acad. Sci. U.S.A. 107, 18251-18255. doi: $10.1073 /$ pnas. 1002098107

Gaines, S. D., White, C., Carr, M. H., and Palumbi, S. R. (2010b). Designing marine reserve networks for both conservation and fisheries management. Proc. Natl. Acad. Sci. U.S.A. 107, 18286-18293. doi: 10.1073/pnas.0906473107

Gamfeldt, L., and Hillebrand, H. (2008). Biodiversity effects on aquatic ecosystem functioning - maturation of a new paradigm. Int. Rev. Hydrobiol. 93, 550-564. doi: 10.1002/iroh.200711022

García-Charton, J. A., Pérez-Ruzafa, A., Marcos, C., Claudet, J., Badalamenti, F., Benedetti-Cecchi, L., et al. (2008). Effectiveness of European AtlantoMediterranean MPAs: do they accomplish the expected effects on populations, communities and ecosystems? J. Nat. Conserv. 16, 193-221. doi: 10.1016/j.jnc.2008.09.007

García-Charton, J. A., Pérez-Ruzafa, A., Sánchez-Jerez, P., Bayle-Sempere, J. T., Reñones, O., and Moreno, D. (2004). Multi-scale spatial heterogeneity, habitat structure, and the effect of marine reserves on Western Mediterranean rocky reef fish assemblages. Mar. Biol. 144, 161-182. doi: 10.1007/s00227-003-1170-0

García-Rubies, A., Hereu, B., and Zabala, M. (2013). Long-term recovery patterns and limited spillover of large predatory fish in a Mediterranean, M. P. A. PLoS ONE 8:e73922. doi: 10.1371/journal.pone.0073922

Gell, F. R., and Roberts, C. M. (2003). Benefits beyond boundaries: the fishery effects of marine reserves. Trends Ecol. Evol. 18, 448-455. doi: 10.1016/S0169-5347(03)00189-7

Gerber, L. R., Botsford, L. W., Hastings, A., Possingham, H. P., Gaines, S. D., Palumbi, S. R., et al. (2003). Population models for marine reserve design: a retrospective and prospective synthesis. Ecol. Appl. 13(Suppl.), S47-S64. doi: 10. 1890/1051-0761(2003)013[0047:PMFMRD]2.0.CO;2

Gerber, L. R., Kareiva, P. M., and Bascompte, J. (2002). The influence of life history attributes and fishing pressure on the efficacy of marine reserves. Biol. Conserv. 106, 11-18. doi: 10.1016/S0006-3207(01)00224-5

Giakoumi, S., Sini, M., Gerovasileiou, V., Mazor, T., Beher, J., Possingham, H. P., et al. (2013). Ecoregion-based conservation planning in the Mediterranean: dealing with large-scale heterogeneity. PLoS ONE 8:e76449. doi: 10.1371/journal.pone.0076449

Gill, D. A., Mascia, M. B., Ahmadia, G. N., Glew, L., Lester, S. E., Barnes, M., et al. (2017). Capacity shortfalls hinder the performance of marine protected areas globally. Nature 543, 665-671. doi: 10.1038/nature21708

Goñi, R., Adlerstein, S., Alvarez-Berastegui, D., Forcada, A., Reñones, O., Criquet, G., et al. (2008). Spillover from six western Mediterranean marine protected areas: evidence from artisanal fisheries. Mar. Ecol. Prog. Ser. 366, 159-174. doi: 10.3354/meps07532

Goñi, R., Quetglas, A., and Reñones, O. (2003). Size at maturity, fecundity and reproductive potential of a protected population of the spiny lobster Palinurus elephas (Fabricius, 1787) from the western Mediterranean. Mar. Biol. 143, 583-592. doi: 10.1007/s00227-003-1097-5

Green, A. L., Maypa, A. P., Almany, G. R., Rhodes, K. L., Weeks, R., Abesamis, R. A., et al. (2015). Larval dispersal and movement patterns of coral reef fishes, and implications for marine reserve network design. Biol. Rev. 90, 1215-1247. doi: $10.1111 /$ brv.12155

Greenstreet, S. P. R., and Rogers, S. I. (2006). Indicators of the health of the North Sea fish community: identifying reference levels for an ecosystem approach to management. ICES J. Mar. Sci. 63, 573-593. doi: 10.1016/j.icesjms.2005.12.009

Grorud-Colvert, K., Claudet, J., Tissot, B. N., Caselle, J. E., Carr, M. H., Day, J., et al. (2014). Marine protected area networks: assessing whether the whole Is greater than the sum of its parts. PLOS ONE 9:e102298. doi: 10.1371 /journal.pone. 0102298

Grüss, A. (2014). Modelling the impacts of marine protected areas for mobile exploited fish populations and their fisheries: what we recently learnt and where we should be going. Aquat. Living Res. 27, 107-133. doi: 10.1051/alr/2014013

Grüss, A., Kaplan, D. M., Guénette, S., Roberts, C. M., and Botsford, L. W. (2011). Consequences of adult and juvenile movement for marine protected areas. Biol. Conserv. 144, 692-702. doi: 10.1016/j.biocon.2010.12.015
Gubbay, S. (2006). Marine Protected Areas. A Review of Their Use for Delivering Marine Biodiversity Benefits. English Nature Research Reports, 688.

Guidetti, P. (2006a). Marine reserves reestablish lost predatory interactions and cause community changes in rocky reefs. Ecol. Appl. 16, 963-976. doi: 10.1890/ 1051-0761(2006)016[0963:MRRLPI]2.0.CO;2

Guidetti, P. (2006b). Potential of marine reserves to cause communitywide changes beyond their boundaries. Conserv. Biol. 21, 540-545. doi: 10.1111/j.1523-1739.2007.00657.x

Guidetti, P., Baiata, P., Ballesteros, E., Di Franco, A., Hereu, B., Macpherson, E., et al. (2014). Large-scale assessment of Mediterranean Marine Protected Areas effects on fish assemblages. PLoS ONE 9:e91841. doi: 10.1371/journal.pone.0091841

Guidetti, P., Milazzo, M., Bussotti, S., Molinari, A., Murenu, M., Pais, A., et al. (2008). Italian marine reserve effectiveness: does enforcement matter? Biol. Conserv. 141, 699-709. doi: 10.1016/j.biocon.2007.12.013

Hackradt, C. W., García-Charton, J. A., Harmelin-Vivien, M., Pérez-Ruzafa, A., Le Diréach, L., Bayle-Sempere, J. T., et al. (2014). Response of rocky reef top predators (Serranidae: Epinephelinae) in and around marine protected areas in the Western Mediterranean Sea. PLoS ONE 9:e98206. doi: 10.1371/journal.pone.0098206

Halpern, B. S., and Warner, R. R. (2002). Marine reserves have rapid and lasting effects. Ecol. Lett. 5, 361-366. doi: 10.1046/j.1461-0248.2002.00326.x

Harmelin-Vivien, M. L., García-Charton, J. A., Bayle-Sempere, J. T., Charbonnel, E., Le Diréach, L., and Ody, D. (2007). "Importance of marine reserves for the population dynamics of groupers (Epinephelinae) in the western Mediterranean," in Second Symposium Mediterranean Groupers, Nice, 91-93.

Harmelin-Vivien, M., Le Diréach, L., Bayle-Sempere, J., Charbonnel, E., García-Charton, J. A., Ody, D., et al. (2008). Gradients of abundance and biomass across reserve boundaries in six Mediterranean marine protected areas: evidence of fish spillover? Biol. Conserv. 141, 1829-1839. doi: 10.1016/j.biocon.2008.04.029

Hastings, A., and Botsford, L. W. (1999). Equivalence in yield from Marine Reserves and Traditional Fisheries Management. Science 284, 1537-1538. doi: $10.1126 /$ science.284.5419.1537

Hilborn, R., and Ovando, D. (2014). Reflections on the success of traditional fisheries management. ICES J. Mar. Sci. 71, 1040-1046. doi: 10.1093/icesjms/fsu034

Hogg, K., Noguera-Méndez, P., Semitiel-García, M., and Giménez-Casalduero, M. (2013). Marine protected area governance: prospects for co-management in the European Mediterranean. Adv. Oceanogr. Limnol. 4, 241-259. doi: 10.4081/aiol.2013.5346

Hopf, J. K., Jones, G. P., Williamson, D. H., and Connolly, S. R. (2016). Fishery consequences of marine reserves: short-term pain for longer-term gain. Ecol. Appl. 26, 818-829. doi: 10.1890/15-0348

Horta e Costa, B., Claudet, J., Franco, G., Erzini, K., Caro, A., and Gonçalves, E. J. (2016). A regulation-based classification system for Marine Protected Areas (MPAs). Mar. Policy 72, 192-198. doi: 10.1016/j.marpol.2016.06.021

Hughes, T. P., Cameron, D. S., Chin, A., Connolly, S. R., Day, J. C., Jones, G. P., et al. (2016). A critique of claims for negative impacts of Marine Protected Areas on fisheries. Ecol. Appl. 26, 637-641. doi: 10.1890/15-0457

Hunt, A., and Taylor, T. (2009). "Values and cost-benefit analysis: economic efficiency criteria in adaptation," in Adapting to Climate Change: Thresholds, Values, Governance, eds W.N. Adger, I. Lorenzoni, and K. O'Brien (Cambridge: Cambridge University Press), 197-211.

IUCN (1988). Resolution 17.38 of the 17th General Assembly of the IUCN. Gland and Cambridge: IUCN.

IUCN (1994). Guidelines for Protected Area Management Categories. Cambridge: IUCN.

IUCN-WCPA (2008). Establishing Resilient Marine Protected Area Networks: Making It happen. IUCN World Commission on Protected Areas (IUCN-WCPA), Washington, D. C., National Oceanic and Atmospheric Administration (NOAA), US Department of Commerce, and The Nature Conservancy. 118.

Jay, S., Alves, F., O’Mahony, C., Gomez, M., Rooney, A., Almodovar, M., et al. (2016). Transboundary dimensions of marine spatial planning: fostering inter-jurisdictional relations and governance. Mar. Policy 65, 85-96. doi: 10.1016/j.marpol.2015.12.025 
Jennings, S., Smith, A. D. M., Fulton, E. A., and Smith, D. C. (2014). The ecosystem approach to fisheries: management at the dynamic interface between biodiversity conservation and sustainable use. Ann. N. Y. Acad. Sci. 1322, 48-60. doi: 10.1111/nyas.12489

Jessopp, M. J., and McAllen, R. J. (2007). Water retention and limited larval dispersal: implications for short and long-distance dispersers in marine reserves. Mar. Ecol. Prog. Ser. 333, 27-36. doi: 10.3354/meps333027

Jones, G. P., Cole, R., and Battershill, C. N. (1993). "Marine reserves: do they work?" in The Ecology of Temperate Reefs: Proceedings of the Second International Temperate Reef Symposium, Auckland, (Wellington: NIWA Publications), 29-45.

Jørgensen, S. E., and Mejer, H. A. (1979). A holistic approach to ecological modelling. Ecol. Model. 7, 169-189. doi: 10.1016/0304-3800(79)90068-1

Kark, S., Levin, N., Grantham, H. S., and Possingham, H. P. (2009). Betweencountry collaboration and consideration of costs increase conservation planning efficiency in the Mediterranean Basin. Proc. Natl. Acad. Sci. U.S.A. 106, 15368-15373. doi: 10.1073/pnas.0901001106

Kelleher, G. (1999). Guidelines for Marine Protected Areas. Gland, Switzerland and Cambridge: IUCN, 107.

Kellner, J. B., Tetreault, I., Gaines, S. D., and Nisbet, R. M. (2007). Fishing the line near marine reserves in single and multispecies fisheries. Ecol. Appl. 17, 1039-1054. doi: 10.1890/05-1845

Kerwath, S. E., Winker, H., Götz, A., and Attwood, C. G. (2013). Marine protected area improves yield without disadvantaging fishers. Nat. Commun. 4, 23-47. doi: $10.1038 /$ ncomms 3347

Klein, C. J., Brown, C. J., Halpern, B. S., Segan, D. B., McGowan, J., Beger, M., et al. (2015). Shortfalls in the global protected area network at representing marine biodiversity. Sci. Rep. 5:17539. doi: 10.1038/srep17539

Kramer, D. L., and Chapman, M. R. (1999). Implications of fish home range size and relocation for marine reserve function. Environ. Biol. Fishes 55, 65-79. doi: 10.1023/A:1007481206399

Lester, S. E., Halpern, B. S., Grorud-Colvert, K., Lubchenco, J., Ruttenberg, B. I., Gaines, S. D., et al. (2009). Biological effects within no-take marine reserves: a global synthesis. Mar. Ecol. Prog. Ser. 384, 33-46. doi: 10.3354/meps08029

Link, J. S., and Browman, H. I. (2014). Integrating what? Levels of marine ecosystem-based assessment and management. ICES J. Mar. Sci. 71, 1170-1173. doi: 10.1093/icesjms/fsu026

Lloret, J., Cowx, I. G., Cabral, H., Castro, M., Font, T., Gonçalves, J. M. S., et al. (2017). Small-scale coastal fisheries in European Seas are not what they were: ecological, social, and economic changes. Mar. Policy doi: 10.1016/j.marpol.2016.11.007

Long, R. D., Charles, A., and Stephenson, R. L. (2015). Key principles of marine ecosystem-based management. Mar. Policy 57, 53-60. doi: 10.1016/j.marpol.2015.01.013

Lubchenco, J., and Grorud-Colvert, K. (2015). Making waves: the science and politics of ocean protection. Science 350, 382-383. doi: 10.1126/science.aad5443

Lubchenco, J., Palumbi, S. R., Gaines, S. D., and Andelman, S. (2003). Plugging a hole in the Ocean: the emerging science of marine reserves. Ecol. Appl. 13, S3-S7. doi: 10.1890/1051-0761(2003)013[0003:PAHITO]2.0.CO;2

Mangi, S. C., and Austen, M. C. (2008). Perceptions of stakeholders towards objectives and zoning of marine-protected areas in southern Europe. J. Nat. Conserv. 16, 271-280. doi: 10.1016/j.jnc.2008.09.002

MAPAMED (2017). The database on Sites of Interest for the Conservation of Marine Environment in the Mediterranean Sea, Med PAN and UNEP/MAP/SPA-RA, April 2017 release.

Marchal, P., Andersen, J. L., Aranda, M., Fitzpatrick, M., Goti, L., Guyader, O., et al. (2016). A comparative review of fisheries management experiences in the European Union and in other countries worldwide: Iceland, Australia, and New Zealand. Fish Fish. 17, 803-824. doi: 10.1111/faf.12147

Margalef, R. (1997). Our Biosphere. Excellence in Ecology Series, ed O. Kinne Oldendorf: Ecology Institute.

Mazor, T., Giakoumi, S., Kark, S., and Possingham, H. (2014a). Large-scale conservation planning in a multinational marine environment: cost matters. Ecol. Appl. 24, 1115-1130. doi: 10.1890/13-1249.1

Mazor, T., Possingham, H. P., Edelist, D., Brokovich, E., and Kark, S. (2014b). The crowded sea: incorporating multiple marine activities in conservation plans can significantly alter spatial priorities. PLoS ONE 9:e104489. doi: 10.1371/journal.pone.0104489
McCauley, D. J. (2014). Mega-parks need greater oversight. Nature 515, 29. doi: 10. 1038/515028a

McCauley, D. J., Woods, P., Sullivan, B., Bergman, B., Jablonicky, C., Roan, A., et al. (2016). Ending hide and seek at sea. Science 351, 1148-1150. doi: $10.1126 /$ science.aad5686

McClanahan, T. R., and Mangi, S. (2000). Spillover of exploitable fishes from a marine park and its effect on the adjacent fishery. Ecol. Appl. 10, 1792-1805. doi: 10.1890/1051-0761(2000)010[1792:SOEFFA]2.0.CO;2

Morgan, L. (2014). Protect diverse marine habitats. Nature 515, 29. doi: 10.1038/ $515028 \mathrm{a}$

Murawski, S. A., Rago, P., and Fogarty, M. (2004). Spillover effects from temperate marine protected areas. Am. Fish. Soc. Symp. 42:167e184.

Murawski, S. A., Wigley, S. E., Fogarty, M. J., Rago, P. J., and Mountain, D. G. (2005). Effort distribution and catch patterns adjacent to temperate MPAs. ICES J. Mar. Sci. 62, 1150-1167. doi: 10.1016/j.icesjms.2005.04.005

Neubert, M. G. (2003). Marine reserves and optimal harvesting. Ecol. Lett. 6, 843-849. doi: 10.1046/j.1461-0248.2003.00493.x

Odum, E. P. (1969). The strategy of ecosystem development. Science 164, 267-270. doi: $10.1126 /$ science.164.3877.262

Pahl, S., Sheppard, S., Boomsma, C., and Groves, C. (2014). Perceptions of time in relation to climate change. WIREs Clim. Change 5, 375-388, doi: $10.1002 /$ wcc. 272

Palumbi, S. R. (2004). Marine reserves and ocean neighborhoods: the spatial scale of marine populations and their management. Annu. Rev. Environ. Res. 29, 31-68. doi: 10.1146/annurev.energy.29.062403.102254

Pascual, M., Rossetto, M., Ojea, E., Milchakova, N., Giakoumi, S., Kark, S., et al. (2016). Socioeconomic impacts of marine protected areas in the Mediterranean and Black Seas. Ocean Coast. Manage. 133, 1-10. doi: 10.1016/j.ocecoaman.2016.09.001

Pastoors, M. A., Rijnsdorp, A. D., and van Beek, F. A. (2000). Effects of a partially closed area in the North Sea ("plaice box") on stock development of plaice. ICES J. Mar. Sci. 57, 1014-1022. doi: 10.1006/jmsc.2000.0586

Patrick, W. S., and Link, J. S. (2015). Myths that continue to impede progress in Ecosystem-Based Fisheries Management. Fisheries 40, 155-160. doi: 10.1080/03632415.2015.1024308

Pauly, D., Alder, J., and Watson, R. (2005). Global trends in world fisheries: impacts on marine ecosystems and food security. Philos. Trans. R. Soc. Lond. B Biol. Sci. 360, 5-12. doi: 10.1098/rstb.2004.1574

Pauly, D., Christensen, V., Guénette, S., Pitcher, T., Sumaila, U. R., Walters, C. J., et al. (2002). Towards sustainability in world fisheries. Nature 418, 689-695. doi: 10.1038/nature01017

Pérez-Ruzafa, A. (2015). El papel de la conectividad restringida en la construcción de los ecosistemas marinos semiaislados: el ejemplo de las lagunas costeras y los archipiélagos. Rev. Acad. Canar. Cienc. 27, 411-456.

Pérez-Ruzafa, A., and Marcos, C. (2012). Fisheries in coastal lagoons: an assumed but poorly researched aspect of the ecology and functioning of coastal lagoons. Estuar. Coast. Shelf Sci. 110, 15-31. doi: 10.1016/j.ecss.2012.05.025

Pérez-Ruzafa, A., Fernández, A. I., Marcos, C., Gilabert, J., Quispe, J. I., and García-Charton, J. A. (2005). Spatial and temporal variations of hydrological conditions, nutrients and chlorophyll a in a Mediterranean coastal lagoon (Mar Menor, Spain) Hydrobiologia 550, 11-27. doi: 10.1007/s10750-005-4356-2

Pérez-Ruzafa, A., González-Wangüemert, M., Lenfant, P., Marcos, C., and GarcíaCharton, J. A. (2006). Effects of fishing protection on the genetic structure of fish populations. Biol. Conserv. 129, 244-255. doi: 10.1016/j.biocon.2005.10.040

Pérez-Ruzafa, A., Martín, E., Marcos, C., Zamarro, J. M., Stobart, B., HarmelinVivien, M., et al. (2008). Modelling spatial and temporal scales for spill-over and biomass exportation from MPAs and their potential for fisheries enhancement. J. Nat. Conserv. 16, 234-255. doi: 10.1016/j.jnc.2008.09.003

Plan Development Team (1990). The Potential of Marine Fishery Reserves for Reef Fish Management in the U.S Southern Atlantic. NOAA Technical Memorandum, NMFS-SEFC-261, Southeast Fisheries Center, Miami, Florida.

Planes, S., García-Charton, J. A., and Pérez Ruzafa, A. (2006). (Coord.) Ecological Effects of Atlanto-Mediterranean Marine Protected Areas in the European Union. EMPAFISH Project, Booklet 1, 158. Available online at http://www.um.es/ empafish/files/WP1\%20Booklet.pdf

Portman, M., Nathan, D., and Levin, N. (2012). From the Levant to Gibraltar: a regional perspective for marine conservation in the Mediterranean Sea. AMBIO 41, 670-681. doi: 10.1007/s13280-012-0298-x 
Pressey, B., McCauley, D. J., Morgan, L., Possingham, H., White, L., Darling, E., et al. (2014). A to-do list for the world's parks. Nature 515, 28-31. doi: $10.1038 / 515028$ a

Rakitin, A., and Kramer, D. L. (1996). Effect of a marine reserve on the distribution of coral reef fishes in Barbados. Mar. Ecol. Prog. Ser. 131, 97-113. doi: 10.3354/meps131097

Rees, S. E., Mangi, S. C., Hattam, C., Gall, S. C., Rodwell, L. D., Peckett, F. J., et al. (2015). The socio-economic effects of a Marine Protected Area on the ecosystem service of leisure and recreation. Mar. Policy 62, 144-152. doi: 10.1016/j.marpol.2015.09.011

Reñones, O., Goñi, R., Pozo, M., Deudero, S., and Moranta, J. (1999). Effects of protection on the demographic structure and abundance of Epinephelus marginatus (Lowe, 1834). Evidence from Cabrera Archipelago National Park (West-central Mediterranean). Mar. Life 9, 45-53.

Roberts, C. M. (2000). Selecting marine reserve locations: optimality versus opportunism. Bull. Mar. Sci. 66, 581-592.

Roberts, C. M., and Hawkins, J. P. (2000). Fully-Protected Marine Reserves: A Guide. WWF Endangered Seas Campaign, Washington, U. S. A., and University of York, UK.

Roberts, C. M., and Polunin, N. V. C. (1991). Are marine reserves effective in management of reef fisheries? Rev. Fishy Biol. Fish. 1, 65-91. doi: $10.1007 / \mathrm{BF} 00042662$

Roberts, C. M., Branch, G., Bustamante, R. H., Castilla, J. C., Dugan, J., Halpern, B. S., et al. (2003). Application of ecological criteria in selecting marine reserves and developing reserve networks. Ecol. Appl. 13, S215-S228. doi: 10.1890/1051-0761(2003)013[0215:AOECIS]2.0.CO;2

Roberts, C. M., Halpern, B., Palumbi, S. R., and Warner, R. R. (2001). Designing Marine Reserve Networks Why Small, Isolated Protected Areas Are Not Enough.Conservation 2, 10-17. doi: 10.1111/j.1526-4629.2001.tb00012.x

Roberts, C. M., O'Leary, B. C., McCauley, D. J., Cury, P. M., Duarte, C. M., Lubchenco, J., et al. (2017). Marine reserves can mitigate and promote adaptation to climate change. Proc. Natl. Acad. Sci. U.S.A. 114, 6167-6175. doi: $10.1073 /$ pnas. 1701262114

Roncin, N., Alban, F., Charbonnel, E., Crec'hriou, R., Modino, R. D., Culioli, J. M., et al. (2008). Uses of ecosystem services provided by MPAs: how much do they impact the local economy? A southern Europe perspective. J. Nat. Conserv. 16, 256-270. doi: 10.1016/j.jnc.2008.09.006

Rossberg, A. G., Uusitalo, L., Berg, T., Zaiko, A., Chenuil, A., Uyarra, M. C., et al. (2017). Quantitative criteria for choosing targets and indicators forsustainable use of ecosystems. Ecol. Indic. 72, 215-224. doi: 10.1016/j.ecolind.2016.08.005

Russ, G. R., and Alcala, A. C. (1996). Do marine reserves export adult fish biomass? Evidence from Apo Island, central Philippines. Mar. Ecol. Prog. Ser. 132, 1-9. doi: 10.3354/meps132001

Russ, G. R., Cheal, A. J., Dolman, A., Emslie, M. J., Evans, R. D., Miller, I. R., et al. (2008). Rapid increase in fish numbers follows creation of world's largest marine reserve network. Curr. Biol. 18, R514-R515. doi: 10.1016/j.cub.2008.04.016

Sadovy de Mitcheson, Y. (2016). Mainstream fish spawning aggregations into fishery management calls for a precautionary approach. BioScience 66, 295-306. doi: 10.1093/biosci/biw013

Sala, E., Costello, C., Dougherty, D., Heal, G., Kelleher, K., Murray, J. H., et al. (2013). A general business model for marine reserves. PLoS ONE 8:e58799. doi: 10.1371/journal.pone.0058799

Sala, E., Costello, C., Parme, J. D. B., Fiorese, M., Heal, G., Sumaila, R. et al. (2016). Fish banks: an economic model to scale marine conservation. Marine Policy 73 , 154-161. doi: 10.1016/j.marpol.2016.07.032

Salas, F., Marcos, C., Neto, J. M., Patricio, J., Pérez-Ruzafa, A., and Marques, J. C. (2006). User-friendly guide for using benthic ecological indicators in coastal and marine quality assessment. Ocean Coast. Manag. 49, 308-331. doi: 10.1016/j.ocecoaman.2006.03.001

Sciberras, M., Jenkins, S. R., Mant, R., Kaiser, M. J., Hawkins, S. J., and Pullin, A. S. (2015). Evaluating the relative conservation value of fully and partially protected marine areas. Fish Fish. 16, 58-77. doi: 10.1111/faf.12044

Selig, E. R., Kleisner, K. M., Ahoobim, O., Arocha, F., Cruz-Trinidad, A., Fujita, R., et al. (2017). A typology of fisheries management tools: using experience to catalyse greater success. Fish Fish. 18, 543-570. doi: 10.1111/faf.12192

Shin, Y. J., and Shannon, L. J. (2010). Using indicators for evaluating, comparing and communicating the ecological status of exploited marine ecosystems. 1. The IndiSeas project. ICES J. Mar. Sci. 67, 686-691. doi: 10.1093/icesjms/fsp294
Shin, Y. J., Shannon, L. J., Bundy, A., Coll, M., Aydin, K., Bez, N., et al. (2010). Using indicators for evaluating, comparing and communicating the ecological status of exploited marine ecosystems. Part 2: Setting the scene. ICES J. Mar. Sci. 67, 692-716. doi: 10.1093/icesjms/fsp294

Smith, A. D. M., and Garcia, S. M. (2014). Fishery management: contrasts in the Mediterranean and the Atlantic. Curr. Biol. 24, R810-R812. doi: $10.1016 /$ j.cub.2014.07.031

Sørensen, T. K. (2006). "Present and past MPAs used in fisheries management in the Northeast Atlantic," in PROTECT WP2 Review of MPAs for Ecosystem Conservation and Fisheries Management, 31-61.

Stelzenmüller, V., Maynou, F., Bernard, G., Cadiou, G., Camilleri, M., Crech'riou, R., et al. (2008). Spatial assessment of fishing effort around European marine reserves: implications for a successful fisheries management. Mar. Pollut. Bull. 56, 2018-2026. doi: 10.1016/j.marpolbul.2008.08.006

Strong, J. A., Andonegi, E., Bizsel, K. C., Danovaro, R., Elliott, M., Franco, A., et al. (2015). Marine biodiversity and ecosystem function relationships: the potential for practical monitoring applications. Estuar. Coast. Shelf Sci. 161, 46-64. doi: 10.1016/j.ecss.2015.04.008

Teixeira, H., Berg, T., Uusitalo, L., Fürhaupter, K., Heiskanen, A. S., Mazik, K., et al. (2016). A catalogue of marine biodiversity indicators. Front. Mar. Sci. 3:207. doi: 10.3389/fmars.2016.00207

Thomas, H. L., Macsharry, B., Morgan, L., Kingston, N., Moffitt, R., StanwellSmith, D., et al. (2014). Evaluating official marine protected area coverage for Aichi Target11: appraising the data and methods that define our progress. Aquatic Conserv. 24, 8-23. doi: 10.1002/aqc.2511

Tilman, D., Isbell, F., and Cowles, J. M. (2014). Biodiversity and ecosystem functioning. Ann. Rev. Ecol. Evol. Syst. 45, 471-493. doi: 10.1146/annurev-ecolsys-120213-091917

Tonn, B., Hemrick, A., and Conrad, F. (2006). Cognitive representations of the future: survey results. Futures 38, 810-829. doi: 10.1016/j.futures.2005. 12.005

Tudela, S., Coll, M., and Palomera, I. (2005). Developing an operational reference framework for fisheries management on the basis of a twodimensional index of ecosystem impact. ICES J. Mar. Sci. 62, 585-591. doi: 10.1016/j.icesjms.2005.01.008

Valiela, I. (1995). "Development of structure in marine communities: colonization and succession," in Marine Ecological Processes, ed I. Valiela (New York, NY: Springer-Verlag), 355-381.

Vandeperre, F., Higgins, R. M., Sánchez-Meca, J., Maynou, F., Goñi, R., MartínSosa, P., et al. (2011). Effects of no-take area size and age of marine protected areas on fisheries yields: a meta-analytical approach. Fish Fish. 12, 412-426. doi: 10.1111/j.1467-2979.2010.00401.x

Vandeperre, F., Higgins, R., Santos, R., and Pérez-Ruzafa, A. (2006). (Coords.) Fishery Regimes in Atlanto-Mediterranean European Marine Protected Areas. EMPAFISH Project. Booklet n², 97. Available online at: http://www.um.es/ empafish/

Vasilakopoulos, P., Maravelias, C. D., and Tserpes, G. (2014). The alarming decline of Mediterranean Fish Stocks. Curr. Biol. 24, 1-6. doi: $10.1016 /$ j.cub.2014.05.070

Waters, J. R. (1991). Restricted access vs. open access methods of management: towards more effective regulation of fishing effort. Am. Fish. Rev. 53, 1-10.

Wood, L. J., Fish, L., Laughren, J., and Pauly, D. (2008). Assessing progress towards global marine protection targets: shortfalls in information and action. Oryx 42, 340-351. doi: 10.1017/S003060530800046X

Worm, B., Hilborn, R., Baum, J. K., Branch, T. A., Collie, J. S., Costello, C., et al. (2009). Rebuilding global fisheries. Science 325, 578-585. doi: $10.1126 /$ science. 1173146

Conflict of Interest Statement: The authors declare that the research was conducted in the absence of any commercial or financial relationships that could be construed as a potential conflict of interest.

Copyright $\odot 2017$ Pérez-Ruzafa, García-Charton and Marcos. This is an open-access article distributed under the terms of the Creative Commons Attribution License (CC $B Y)$. The use, distribution or reproduction in other forums is permitted, provided the original author(s) or licensor are credited and that the original publication in this journal is cited, in accordance with accepted academic practice. No use, distribution or reproduction is permitted which does not comply with these terms. 